\title{
Socio-Cultural Barriers To Women Empowerment: A Case Study Of Women Working In Vocational Training Institutes Of District Kohat
}

\author{
Zia Ullah Akhunzada \\ Mamoon Khan Khattak \\ Department of Social Work \\ Kohat University of Science \& Technology
}

Adnan Ashraf

Child Protection Unit Kohat

\begin{abstract}
The study underlines the socio-cultural obstacles to women's empowerment in the target area. Kohat district was chosen as locale of the study. 78 women working in 3 different Technical and Vocational Training Institutes were randomly interviewed for the study. Structured interview schedule was used as tool for collecting data from the sample respondents. The results of the study indicate that Socio-Cultural hindrances exist and are obstructing women empowerment in the target area. The condition can be improved by creating socio-cultural values favourable to women empowerment through education, jobs, decision-making power and by avoiding misinterpretation of religion etc.
\end{abstract}

Keywords: Empowerment, Barriers, Society, Family

$$
\begin{aligned}
& \text { ثلخيص }
\end{aligned}
$$

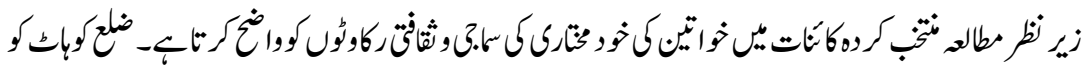

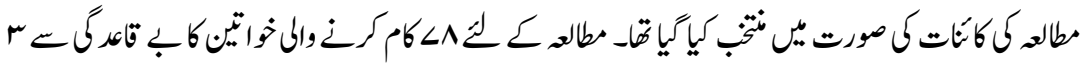

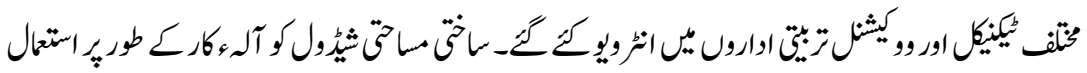

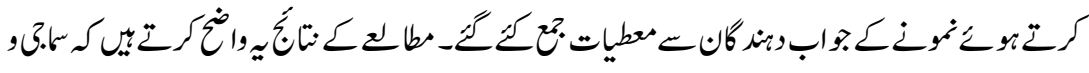

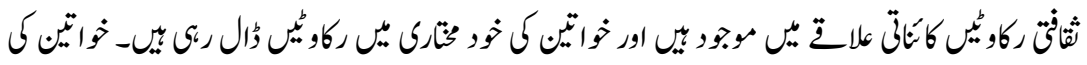




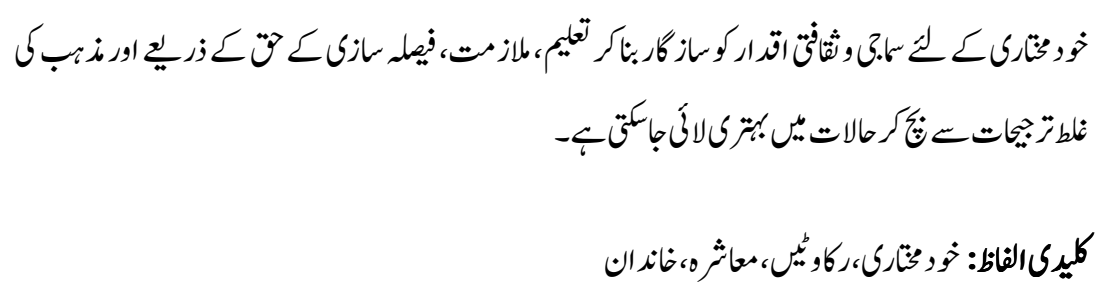

\section{Introduction}

Mason and Smith (2003) stated that women's empowerment absolutely imposes that in all the human societies, men commands women, or to be further specific, males control at least small segment of the women of their societal strata, especially of their families and households. In this outlook, women are a "class" in the gender stratification structure, a system that is controlled by common values and norms. Girls and women comprise $3 / 5$ of the poor among the world. The rate of poverty is high and is poorer than that of males as evident gender disparities in education, jobs and decision-making power exists (Siddiqui and Nasir, n.d). Women are still mostly isolated into occupations that are less paid than those typically taken by men (Narasaiah, 2004). Chodorow (1978) states that women are less healthy, nourished and are more helpless than men. The patriarchal nature of societal structure in Pakistan provides women less likelihood to get hold of land, low level of legal support for justice and little opportunities for political participation. They have to surpass a number of socio-cultural barriers in order to work for money. They are considered as tool of delivering kids, looking after members of family and giving them passionate happiness. Women do hardly have time to think about themselves. They have lost their individuality while fulfilling their responsibilities. In usual time, majority of the women don't have their own goals rather they react to the demands and needs of others. Additionally, their literacy ratio significantly indicates that investment in human capacities inclines toward males over women (Skalli, 2001). Pakistan has the lowest literacy rate of $49.9 \%$ among the South Asian countries. In Pakistan the women literacy ratio is $35.2 \%$ which steps down to $25 \%$ in villages while $55 \%$ enrolment in girl's school has dropped to $25 \%$ (Latif, 2009). The socio-economic empowerment of Pakistani women is yet to achieve a satisfactory level, stated by Global Gender Gap Report 2007 (Augusto \& Saadia, 2005).

In Pakistan women have mostly been considered as second class citizens due to socio-cultural, economic and legal constraints. Although, half of the Pakistani 
population consists of women folk but their empowerment is not encouraging (Naz, Ibrahim \& Ahmad, 2012). Jehan (2000) states that impediments on women strengthening start from social practices and convictions. Patriarchal based control is legitimized and practiced on the premise of society, a composite of custom, and religion which decides and characterizes the endorsed part of women in the public arena, their versatility and their admission to financial assets, social and political power too. A woman is barred from saying anything in regards to her life not even in her matrimonial affairs. Once affianced, she rests completely to her spouse's family.

Since, decision-making power is dead set on the strength of male hierarchy, it is also very hard for women officers in public and private sector to devise, plan or execute gender sensitive approaches and even to get sufficient funds to try to do so (Augusto \& Saadia, 2005).

Dyson and Moore (1983), states that empowerment is the ability to acquire information and making decisions regarding one's personal concern plus those of one's dear. Empowerment is said to be the amount of access to control over social resources and material within micro and macro level (Dixon Muller, 1978).First definition deals with the decision-making while the second covers the area of women access and control over resources. However, Batliwala (1995) and Malhotra (2002) term empowerment as a process by which women obtain larger command over intellectual and material resources, which help them to raise their self-dependence and increase them to laid stress on their rights and dare the philosophy of patriarchy and the gender based prejudice against women. This will enable them to organize themselves to affirm their self-sufficiency to make decisions and choices, and ultimately eradicate their own sub-ordination in all institutions and structure of the society.

The problems of gender inequality and gender discrimination are the hindrances in the way of empowerment (Sathar \& Lloyd, 1994). In Pakistan, patriarchy is the pre-dominated social system. This system favours inflexible separation of work and controlled women's liberty of progress and development. It sternly characterizes women's role in daily affairs. Status of general woman is linked with her family, she play essentially significant role in keeping up family by bearing and raising kids and looking after the aged members of her family. There is more noteworthy inequality among men and women in the field of education, jobs, political participation, decision-making, controlling the assets and access to 
health services. Investment in women's education is always very low in Pakistan. Their situation in the family and in the society is measured not acceptable in the framework where women are discriminated (Tisdell, 2002).

Besides the cultural construct of gender roles, this inequality is also due to an insufficient amount of women vocational and professional training institutions. Likewise, the gender ratio in government run universities is recorded as 30-35\%. The amount of women polytechnic institutes are also incredibly less. Education empowers women to manage their lives and provides them better chance and choice to make their own lives and that of their families comfortable. It is the key to get rid of repressive custom and traditions that have annulled the wants of women and girls (Khan, 2007).

The empowerment of women is understood as the core issue for shaping the status of women. Among the socially underprivileged groups, the women are prey of gender prejudice and denial. There is still a long way to go to make sure complete gender equality despite of the development in executing women's empowered and gender sameness programmes in the national plan. The efforts for eradicating discrimination and deprivation should base on gender equality; otherwise it will cease to bear any fruit and would be detrimental for family as well as for the whole society. Empowerment and gender equality are rudiments in achieving sustainable socio-cultural, political and economic security within all individuals (Delavandem \& Zafar, 2013).

Women's empowerment is obligatory for socio-economic development of a country. Empowering women by growing their rank and independence inside families is vital to various global health and development programmes. One of the eight Millennium Development Goals calls for attaining gender fairness and women's empowerment, empowering women is also fundamental to attain various of other goals together with lessening child death, enhancing maternal well-being, accomplishing universal primary education, fighting HIV/ AIDS and the prime goal of decreasing significantly the extent of destitute by the year 2015 (Kabeer, 2003).

\section{Methodology}

The research study was undertaken in Kohat. The study focused on women working in Technical and Vocational Training Centres in Kohat. 03 Vocational 
Training Institutes were selected randomly and data was collected from 78 female respondents out of total 405. Data was collected through structured Interview Schedule and has been entered through SPSS and analysed quantitatively. The distribution of population size and sample of each Technical and Vocational Centre is shown in Table-1 while using the formula given by Kumar (2005).

Sample Size and Distribution of Population

\begin{tabular}{|l|c|c|}
\hline Sample Centre & Total Trainees & Sample Size \\
\hline $\begin{array}{l}\text { Fauji Foundation Vocational } \\
\text { Training Centre }\end{array}$ & 140 & 27 \\
\hline $\begin{array}{l}\text { Social Welfare and Women } \\
\text { Development Centre }\end{array}$ & 85 & 17 \\
\hline $\begin{array}{l}\text { Government Technical and } \\
\text { Vocational Centre }\end{array}$ & 180 & 34 \\
\hline Total & $\mathbf{4 0 5}$ & $\mathbf{7 8}$ \\
\hline
\end{tabular}

Source: Office of the Concerned Centre.

$\mathrm{ni}=\mathrm{n} \times \mathrm{Ni}$

$\mathrm{N}$

$\mathrm{n}=$ Sample size of total population

ni $=$ Sample size of each centre

$\mathrm{Ni}=$ Number of the trainee in each centre

$\mathrm{N}=$ Total number of trainee

\section{Results and Discussions}

Table: 1

Social Constraints in Women Empowerment

\begin{tabular}{|l|l|l|l|c|}
\hline Statements & $\begin{array}{c}\text { Strongly } \\
\text { agree }\end{array}$ & Agree & Disagree & Total \\
\hline $\begin{array}{l}\text { Discrimination in } \\
\text { family assets }\end{array}$ & $30(38.4 \%)$ & $41(52.6 \%)$ & $7(9.0 \%)$ & $78(100.0 \%)$ \\
\hline $\begin{array}{l}\text { Fewer opportunities } \\
\text { of job for females }\end{array}$ & $19(24.4 \%)$ & $43(55.1 \%)$ & $16(20.5 \%)$ & $78(100.0 \%)$ \\
\hline $\begin{array}{l}\text { Violence in work } \\
\text { places result in resign } \\
\text { from job }\end{array}$ & $26(33.3 \%)$ & $45(57.7 \%)$ & $7(9.0 \%)$ & $78(100.0 \%)$ \\
\hline
\end{tabular}




\begin{tabular}{|l|l|l|l|l|}
\hline $\begin{array}{l}\text { Facilitated through } \\
\text { insufficient dowry }\end{array}$ & $15(19.2 \%)$ & $55(70.5 \%)$ & $8(10.3 \%)$ & $78(100.0 \%)$ \\
\hline $\begin{array}{l}\text { Low participation in } \\
\text { politics }\end{array}$ & $13(16.7 \%)$ & $53(67.9 \%)$ & $12(15.4 \%)$ & $78(100.0 \%)$ \\
\hline $\begin{array}{l}\text { Lack of vocational } \\
\text { and professional } \\
\text { opportunities }\end{array}$ & $14(17.9 \%)$ & $49(62.8 \%)$ & $15(19.2 \%)$ & $78(100.0 \%)$ \\
\hline Physically tortured & $25(32.1 \%)$ & $40(51.3 \%)$ & $13(16.7 \%)$ & $78(100.0 \%)$ \\
\hline Dependent on males & $21(26.9 \%)$ & $48(61.5 \%)$ & $9(11.5 \%)$ & $78(100.0 \%)$ \\
\hline $\begin{array}{l}\text { Lack of health } \\
\text { services }\end{array}$ & $17(21.8 \%)$ & $37(47.4 \%)$ & $24(30.8 \%)$ & $78(100.0 \%)$ \\
\hline
\end{tabular}

Table 01 shows that out of the total 78 (100\%) respondents 30 (38.4\%) respondents strongly and $41(52.6 \%)$ agreed that they are discriminated in their family assets while the remaining 7(9.0\%) respondent disagreed. 19 (24.4\%) respondents strongly and $43(55.1 \%)$ agreed that there are fewer opportunities of jobs for females while the remaining 16 (20.5\%) respondents disagreed. 26 $(33.3 \%)$ respondents strongly and $45(57.7 \%)$ agreed that violence in work places result in resignation from job while the remaining $7(9.0 \%)$ respondents were disagree. $15(19.2 \%)$ respondents were strongly and $55(70.5 \%)$ were agree that they have been facilitated through insufficient dowry while the remaining $8(10.3 \%)$ respondents were disagree. $13(16.7 \%)$ respondents were strongly and $53(67.9 \%)$ were agree that role of women in politics is low while the remaining $12(15.4 \%)$ respondents were disagree. $14(17.9 \%)$ respondents were strongly and $49(62.8 \%)$ were agree that they have lack of vocational and professional opportunities while the remaining $15(19.2 \%)$ respondents were disagree. 25 $(32.1 \%)$ respondents were strongly and $40(51.3 \%)$ were agree that they suffer from physical torture while the remaining $13(16.7 \%)$ respondents were disagree. $21(26.9 \%)$ respondents were strongly and $48(61.5 \%)$ were agree that they are dependent on males while the remaining $9(11.5 \%)$ respondents were disagree. 17 $(21.8 \%)$ respondents were strongly and $37(47.4 \%)$ were agree that they have lack of health services while the remaining $24(30.8 \%)$ respondents were disagree. 
Table: 2

Cultural Constraints in Women Empowerment

\begin{tabular}{|l|c|c|c|c|}
\hline Statements & $\begin{array}{c}\text { Strongly } \\
\text { agree }\end{array}$ & Agree & Disagree & Total \\
\hline $\begin{array}{l}\text { No participation in } \\
\text { decision making process }\end{array}$ & $38(48.7 \%)$ & $35(44.9 \%)$ & $5(6.4 \%)$ & $78(100.0 \%)$ \\
\hline Less favour than boys & $37(47.4 \%)$ & $37(47.4 \%)$ & $4(5.1 \%)$ & $78(100.0 \%)$ \\
\hline $\begin{array}{l}\text { Family restriction on } \\
\text { doing certain jobs }\end{array}$ & $12(15.4 \%)$ & $49(62.8 \%)$ & $17(21.8 \%)$ & $78(100.0 \%)$ \\
\hline $\begin{array}{l}\text { Restrictions on women's } \\
\text { mobility }\end{array}$ & $5(9.1 \%)$ & $41(74.5 \%)$ & $9(16.4 \%)$ & $78(100.0 \%)$ \\
\hline $\begin{array}{l}\text { Restriction on Female } \\
\text { education }\end{array}$ & $12(15.4 \%)$ & $44(56.4 \%)$ & $22(28.2 \%)$ & $78(100.0 \%)$ \\
\hline $\begin{array}{l}\text { Provide inadequate } \\
\text { meals }\end{array}$ & $15(19.2 \%)$ & $27(34.6 \%)$ & $36(46.2 \%)$ & $78(100.0 \%)$ \\
\hline $\begin{array}{l}\text { Considered as an } \\
\text { economic liability due to } \\
\text { the dowry system }\end{array}$ & $9(11.5 \%)$ & $51(65.4 \%)$ & $18(23.1 \%)$ & $78(100.0 \%)$ \\
\hline
\end{tabular}

Table 02 shows that out of the total 78 (100\%) respondents 38 (48.7\%) respondents were strongly and $35(44.9 \%)$ were agree that they are not allowed to participate in decision making process while the remaining $5(6.4 \%)$ respondents were disagree. $37(47.4 \%)$ respondents were strongly and $37(47.4 \%)$ were agree that they are less favoured than boys while the remaining $4(5.1 \%)$ respondents were disagree. $12(15.4 \%)$ respondents were strongly and 49 (62.8\%) were agree that they have restrictions from their family on doing certain jobs while the remaining $17(21.8 \%)$ respondents were disagree. $5(9.1 \%)$ respondents were strongly and $41(74.5 \%)$ were agree that there are restrictions on women's mobility while the remaining $9(16.4 \%)$ respondents were disagree. $12(15.4 \%)$ respondents were strongly and $44(56.4 \%)$ were agree that there are restrictions on female's education while the remaining $22(28.2 \%)$ respondents were disagree. 15 (19.2\%) respondents were strongly and 27 (34.6\%) were agree that inadequate meals are provided to them while the remaining $36(46.2 \%)$ respondents were disagree. $9(11.5 \%)$ respondents were strongly and $51(65.4 \%)$ were agree that they are considered as an economic liability due to the dowry while the remaining $18(23.1 \%)$ respondents were disagree. 


\section{Conclusions}

The study concludes that women are discriminated in family material goods. They are provided less opportunity than males in education, employments and in other fields. The study finds that women are discriminated in all walks of life and which is making them handicapped and obstructing their empowerment. Women are considered as burden and debarred from their fundamental rights.

There is a need of promoting education particularly of women, provision of employment opportunities to women, eradication of gender-based discrimination and propagation of Islamic injunctions regarding women's rights in order to empower women in all walks of life. There is a need of harmonizing male dominancy, to make sure equivalent voice of women in decision-making, promotion of vocational training for women, ensuring protection at place of work, elimination of health inequalities, discarding limitations on women's participation, harmonizing role of women in the domestic setting and elimination of unnecessary cultural taboos.

\section{References}

Augusto, C. L. \& Saadia, Z. (2005). Report on Women's Empowerment: Measuring the Global Gender Gap.

Batliwala, S. (1995). Education for Women's Empowerment, ASPBAE Position Paper for the Fourth World Conference on Women, Beijing September (1995). New Delhi, Asia South Pacific Bureau of Adult Education, Conference Proceedings.

Chodorow, N. (1978). The Reproduction of Mothering Psychoanalysis is and the Sociology of Gender, Berkeley, University of California.

Delavande, A., \& Zafar, B. (2013). Gender Discrimination and Social Identity: Experimental Evidence from Urban Pakistan, New York, Federal Reserve Bank of New York.

Dixon-Mueller, R. (1978). Women and New World Economy is an Islands Experience, Women in Management Review, vol.17:7, pp.308-317. 
Dyson, T. \& Moore. M. (1983).On Kinship Structure, Female Autonomy and Demographic Behaviour in India, Population and Development Review, vol.9, pp.35-60.

Jehan, Q. (2000). Role of Women in Economic Development of Pakistan, Thesis Submitted to the Pakistan Study Centre University of Baluchistan, Quetta. Unpublished Ph.D Thesis.

Kabeer, N. (2003). Gender Mainstreaming in Poverty Eradication and the Millennium Development Goals: A Handbook for Policy-makers and Other Stakeholders, UK Commonwealth Secretariat.

Khan, S. A. (2007). Gender Issues in Higher Education in Pakistan, The Bulletin, No. 162.

Kumar, R. (2005). Research Methodology: A Step by Step Guide for Beginners ( $2^{\text {nd }}$ ed.), Sage Publication Ltd. London, UK.

Latif, A. (2009). A Critical Analysis of School Enrolment and Literacy Rates of Girls and Women in Pakistan, Educational Studies, vol.45:5, pp.424-439.

Mahmood, S. (June 22, 2008). Feminization, The Dawn News, Karachi.

Malhotra, A. (2002). Measuring Women's Empowerment as a Variable in International Development, Paper Prepared for the World Bank Workshop on Poverty and Gender; New Perspective Final Version, Conference Proceedings.

Mason, K.O. \& Smith, H.L. 2 January (2003). Women's Empowerment and Social Context: Results from Five Asian Countries, USA.

Narasiah, M.L. (2004). Women and Microcredit, Sonali Publications, New Delhi.

Naz, A. Ibrahim \& Ahmad, W. (2012). Socio-Cultural Impediments to Women Political Empowerment in Pakhtun Society, Academic Research International, vol.3:1, pp.163-173. 
Sathar, Z.A., \& Lloyd. C.B. (1994). Who Gets Primary Schooling in Pakistan? Inequalities Among and Within Families, Pakistan Development Review vol.33:2, pp.103-34.

Siddiqui, H. S \& Nasir, A. J. (n.d). Impact of Women Entrepreneurship on Poverty Alleviation, Review Paper, The Islamia University of Bahawalpur, Pakistan.

Skalli, L. H. (2001). Women and Poverty in Morocco: The Many Faces of Social Exclusion, Feminist Review, vol.69, pp.73-89

Tisdell, C. (2002), Gender Inequality in India: Evidence from a Survey in Rural West Bengal, International Journal of Social Economics, vol.29:9, pp.706-721.

World Economic Forum (91-93). Route De La Capite, CH-1223 Cologny/Geneva, Switzerland, p.12.

Zia Ullah Akhunzada is Lecturer in the Department of Social Work, Kohat University of Science \& Technology, Kohat.

Dr. Mamoon Khan Khattak is Assistant Professor in the Department of Social Work, Kohat University of Science \& Technology, Kohat.

Adnan Ashraf is Child Protection Officer in the Child Protection Unit, Kohat. 